\title{
Aspects of Nature in Nissim Ezekiel's Poetry: an Exploration of Indian Cultural Ethos
}

\author{
Dr. Sandeep K. Thorat \\ Assistant Professor of English \& Head, S. S. S. K. R. Innani College, Karanja Lad, Dist. Washim. \\ *Corresponding Author: Dr. Sandeep K. Thorat, Assistant Professor of English \& Head, S. S. S. K. R. \\ Innani College, Karania Lad, Dist. Washim.
}

\begin{abstract}
In this paper, an attempt is made to focus an aspect of naturein Ezekiel's poetry. His poetry is marked with romantic mood and a realistic portrayal of Indian milieu. His poetry explores the sensitive themes like superstitions, man-woman relationship, husband-wife relationship, marriages, ethos of Indian woman, ethos of urban life, love and sex etc. Besides, Ezekiel's love for nature in his poetry tries to touch Indian cultural ethos. In short, an aspect of nature is mirrored in his poetry having the shades of cultural ethos. Ezekiel seems to be the critic of Indian society as he has a deep sense of social conscience and nature. Ezekiel is called the poet of typical Indian environment. He is an Indian poet having fresh, modern and original approach to nature. Nature is necessary for fruitful living and the elements of nature are symbolic of ethical values in his poetry. The aspects of nature likestorm, thundering, lightning, ghost, some birds like owl, bats are treated as symbols of blind beliefs in his poetry.
\end{abstract}

Keywords: Ezekiel, Nature, Exploration, Cultural Ethos.

Ezekiel has sustained quality of verse to Indian English Poetry. He is recognized as a major poet in the history of Indian English Poetry. Almost every critic in and outside has taken special care of Ezekiel's poetry because of its unique characteristics. "His respect for craft makes his poetry much more than a mere fulsome expression of an emotion or an idea" (Abidi 287). Ezekiel could achieve these characteristics to his poetry because of his Indianness. It was his close relations with Indian environment that endowed a rare significance to his poetry.

Ezekiel's love for nature cannot be ignored while coming in terms of Indian ethos and culture. Indeed, nature has immense importance in Indian cultural ethos. Nature is necessary for fruitful living and the elements of nature are symbolic of ethical values in Ezekiel's poetry:

There is a landscape certainly, the sea

Among its broad realities, attracts

Because it is a symbol of the free

Demonic life within,

Hardly suggested by the surface facts,

And rivers what a man can hope to win

By simple flowing, learning how to flow,

Besides that all organic growth is slow. (CP 39)

In his poem "Song," Ezekiel presents blossoms of summer as symbol of prosperity, charity and lucidity which are the aspects of Indian culture: "Charity, lucidity - / Remarkable in the mood of seems / The doom of all my traffic dreams" (CP 42).

Rainwater is a traditional symbol of Indian culture and consequently rain brings prosperity in the life of an Indian farmer. Ezekiel, in "After Rain," describes the rain as a symbol of purification of life:

And so I went, as the weather cleared,

Walking on the wet road, to know 
If the scene had taken on a novel glow,

Lamlight, moonlight, dripping branches, wet road

Purer, sweeter, and now I know,

It is just so. (CP 63)

Ezekiel's skills of presenting blind beliefs must be worshiped in terms of Indian ethos and culture. In India, the elements of nature like storm, thundering, lightning, ghost, some birds like owl, bats are treated as symbols of blind beliefs. In his poem "Occupation" Ezekiel depicts these symbols of blind beliefs:

It was a stormy scene:

Thunder, lightning,

A multitude of ghost among the trees,

Darkness, cold and restlessness,

A screeching owl, bats,

Many strange voices,... (CP 24)

Birds like owl and bats are looked upon signs of bad omen in Indian society. The black bird 'crow' is also looked down upon and considered as a messenger of Yama (God of death) in Hinduism. In "The Crows", the poet expresses contempt and displeasure at the cry of this bird:

I hear them from my narrow bed,

I do not love, I only fear

Their cries of hidden duty's word,

Unwelcome, loud, funereal bird. (CP 41)

Ezekiel presents nature as a symbol of purity and tranquility. Nature for Ezekiel is a guiding aspect to seek truth in life. In his use of imagery from the object of nature, he searches the past ethos and culture of India. In A Time to Change, the poet recalls "new orchids or unimagined seas", and "discovery of cities fresh as brides". In "A Word for the Wind," the poet considers the wind as a source of inspiration. In "Stone," the poet finds consolation in the objects of nature and makes himself a worshiper of nature exactly like that of William Wordsworth.

Ezekiel's poetry also focuses on his interest in ornithology and natural history. It may confess that animals also have emotions like human beings. They, too, can take interest in the act of making love among themselves. In his poem "Aside", it larks clearly that the animals can be restless for sex like human beings:

One cannot imagine

Elephants making love,

But it seems they do

So also tortoises

And snails,

Or even other men

With women doing

What it seems they do. (CP 93)

It is an interesting and realistic observation of the environment by Ezekiel in which he lives. Ezekiel's "The Behaviour of Love Birds," pictures the lustful trails faced by a pair of animals:

The more the female fluffs

the readier she is,

and the more the male is encouraged,

Finally, she solicits copulation

by leaning forward, 
raising her head,

and her

tail.

Newly formed pairs

are rather awakward.

The males make many mistakes,

are frequently threatened

and thwarted

by their mates. (n.pag.)

Ezekiel's visualization of the act of copulation in the world of animals is astonishing to the human minds. It seems that he wants to accept that if animals cannot live without sex, how can human beings. He exposes the fact that carnal desire is natural instinct and man and woman cannot live a happy life without the gratification of sex. In fact, the poet is aware of the elements of nature and it happenings and the eternal reality. He does not only try to bring out the cultural ethos of the human beings, but also that of the other animals on this planet.

The piece "Urban" in The Unfinished Man is a remarkable poem on the urban theme where the trees appear to him like ghosts losing their personal identity. He employs various images from the objects of nature in his poem "Urban":

The hills are always far away.

He knows the broken roads, and moves

In circles tracked within his head.

Before he wakes and has his say,

The river which he claims he loves

Is dry, and all the winds lie dead.

At dawn he never sees the skies

Which, silently, are born again.

Nor feels the shadow of the night

Recline their fingers on his eyes,

He welcomes neither sun nor rain.

His landscape has no depth or height. (CP 117)

These images of hills, rivers, wind, skies, sun and rain represent the polarity to the image of the city. Perhaps, these objects of nature denote ethical values and smooth flow of culture. They have become the archetypal life symbols. As K. D. Verma points out that:

[T] hey project a pastoral vision of a fully refulgent and harmonious life, a pattern in which man enters into sacred communion with his cosmos including objects of nature as a metaphoric condition of his integrated humanity and of his desire to foster a community of being. (231)

The poem also reminds us the same feeling about the city of London expressed by T. S. Eliot in his poem "The Waste Land." Eliot depicts the degeneration of the society and therefore the city of London has become wasteland. Similarly, Ezekiel states his feeling about the city of Bombay in "Urban":

The city like a passion burns,

He dreams of morning walks, alone,

and floating on a wave of sand.

But still his mind its traffic turns

Away from branch and tree and stone 
To kindred clamour close at hand. (CP 117)

The poem reflects the changing ethos and culture of the urban man. He is confused without any aim of life, as human desires are never fulfilled. His passion for sex is unlimited. Hence, his degeneration is ultimate. Bijay Kumar Das comments on the poem and the poet:

As a man strives to exist in a modern urban society, to search for truth and to realize identity with the self and the community his struggles, failures and frustrations reveal not only his own inward nature but also the insufficiency and frailty of the fallen city.......... 'Urban' is a very compact poem so far as the imagery is concerned. The city that 'like a passion burns' is the image of the bride, and in an ideal sense a complete sexual union would mark the realization of fullness and identity. Since the persona merely 'dreams' and shies away from her, the use of the keyword 'kindred' in the last line turns out to be ironical. Thus what the persona achieves is a kind of illusory union with the 'city' and this forms a kind of habitual response to it. (19)

A. K. Ramanujan too echoes the voice like that of Ezekiel in his poem "A River." Ramanujan narrates the ethos and culture of the historical river Vaikai in Madurai. The poet sings the past glory of Madurai, the city of temples and poets:

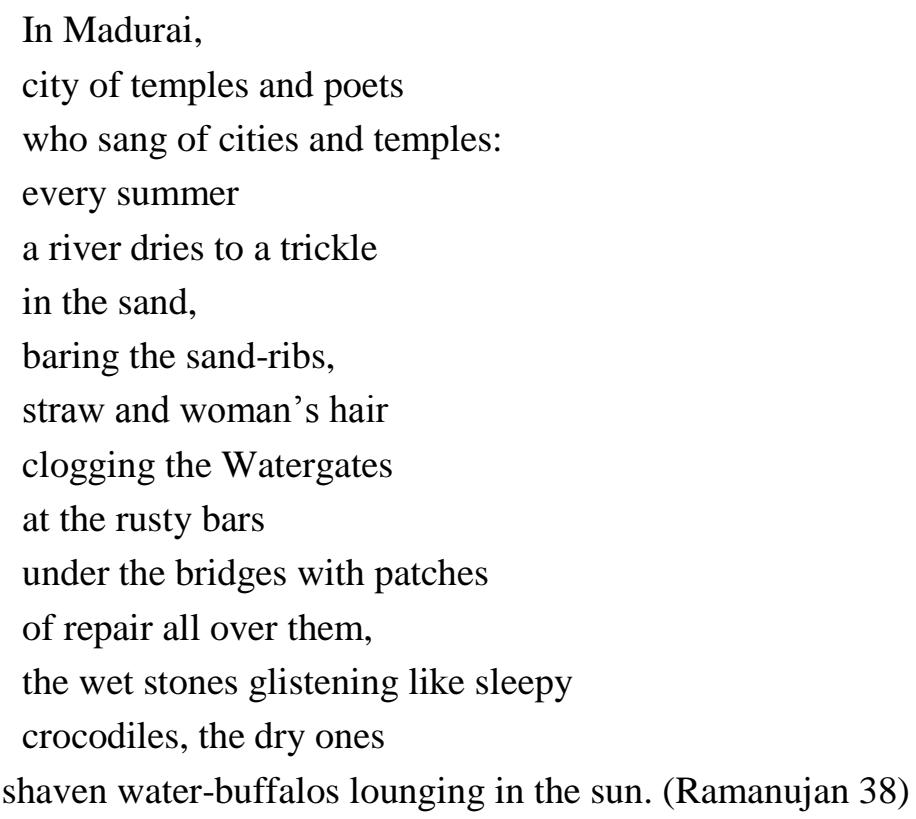

In fact, Ramanujan shows that the holy river Vaikai which flows through Madurai, a city that has history of Tamil culture for about two thousand years. The river remains no more of significance for it carries the hair of woman. The bridge is old full of patches of repair. The water has lost its purity for buffalos are seen taking rest in it. He creates the images of "wet stones" and "sleepy crocodiles." Therefore, the state of dehumanizing is on the verge.

Indeed, Ezekiel tries to expose Indian attitude of a common man from the experiences of real life through various elements of nature. He focuses their typical, superstitious, traditional, patriotic, organizational, religious, social, political, psychological attitudes which help to express Indian ethos and culture in his poetry. Moreover, his description of nature helps to bring forth thethemes of love and sex, man-woman relationship, religious-philosophical strain, human failure and so on. All these factors render him a position of a critic of Indian society. In fact, the overall discussion in this paper confirms its aptness in terms of reflection of Indian cultural ethos through the aspects of nature in his poetry.

\section{REFERENCES}

[1] Abidi, S. Z. H. Studies in Indo Anglian Poetry. Bareilly: Prakash Book Depot, 1978. 287. Print.

[2] Das, Bijay Kumar. "Imagery in the Poetry of Nissim Ezekiel." Perspectives on Nissim Ezekiel. Ed. S.C. Dwivedi. New Delhi: Kitab Mahal, 1989. 12-19. Print. 
[3] Ezekiel, Nissim. Collected Poems. New Delhi: O.U.P., 2005. Text. All subsequent references to Ezekiel's poems shall be from this edition.

[4] Mishra, Sanjit. The Poetic Art of Nissim Ezekiel. New Delhi: Atlantic P. and Distributors, 2001. 50-118. Print.

[5] Ramanujan, A. K. Collected Poems. Delhi: OUP, 1997. 38. Text.

[6] Verma, K. D. "Myth and Imagery in the Unfinished Man: A Critical Reading." Journals of South Asian Literature. 11.3-4 (Spring-Summer 1976): 231. Print.

\section{AUTHOR's BIOGRAPHY}

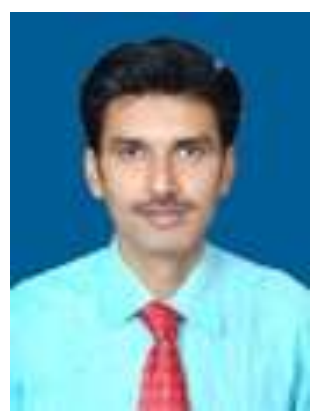

Dr. Sandeep K. Thorat born at Akot, the Tehsil place in Maharashtra, India on $5^{\text {th }}$ Nov. 1973. He qualified M. A. in English (Master of Arts) and M. Phil. from SantGadge Baba Amravati University, Maharashtra, India in 1996 and Alagappa University, Karaikudi, Tamil Nadu in 2008 respectively. He also completed his Ph. D. in English on the topic Indian Ethos and Culture in Nissim Ezekiel's Poetry: A Critical Study from SantGadge Baba Amravati University, Maharashtra, India in 2017.

He has been working as a head, the department of English at S. S. S. K. R. Innani Mahavidyalaya, Karanja Lad, Dist. Washim, Maharashtra, Indiasince 1998. He contributed 29 research papers in peer reviewed journals. He presented 23research papers in various Conferences, Seminars and Workshops at National and International levels .He attended 42Conferences, Seminars and Workshops at National and International levels. Besides, he completed his Minor Research Project on the topic Teaching English through Grammar-Translation Method in Rural India like Washim District: an Analytical Study under UGC, New Delhi.

Besides, he worked as a Member and an Organizing Secretary on various organizing committees for the organization of UGC Sponsored National/International Conferences/Workshops. He also organized several Collegiate - Inter-Collegiate Workshops and Seminars for the students on English Language .He worked as a Secretary for the college Staff Council too.

Citation: Sandeep K. Thorat. "Aspects of Nature in Nissim Ezekiel's Poetry: an Exploration of Indian Cultural Ethos." International Journal On Studies In English Language And Literature (IJSELL), vol 5, no. 11, 2017, pp. 4-7. doi:http://dx.doi.org/10.20431/2347-3134.0511002.

Copyright: (C) 2017 Authors. This is an open-access article distributed under the terms of the Creative Commons Attribution License, which permits unrestricted use, distribution, and reproduction in any medium, provided the original author and source are credited. 